\title{
HOMOLOGY AND FUNCTIONAL MORPHOLOGY OF THE SEXUAL DIMORPHISM IN THE ANTENNA OF SCLEROCYPRIS SARS, 1924 (CRUSTACEA, OSTRACODA, MEGALOCYPRIDINAE)
}

\section{KOEN MARTENS}

\author{
Institute of Ecology, State University of Gent, K. L. Ledeganckstraat 35, B-9000 Gent, Belgium
}

\begin{abstract}
The sexual dimorphism in the chaetotaxy of the antenna in various species of Sclerocypris is studied and described. Relying on larval morphology, a homology between the patterns in the two sexes is deduced and a suitable nomenclature for the apomorphic male condition is proposed. The differences observed are in all probability related to the function of the male antenna during copulation.
\end{abstract}

\section{RÉSUMÉ}

Le dimorphisme sexuel de la chétotaxie de l'antenne dans quelques espèces de Sclerocypris est étudié et décrit. La morphologie larvaire nous a permis d'établir une homologie entre les structures dimorphes dans les deux sexes. Une terminologie adaptée pour la condition apomorphe du mâle est proposée. Les différences observées sont probablement liées aux fonctions de l'antenne mâle pendant la copulation.

\section{INTRODUCTION}

The genus Sclerocypris was recently revised and all taxa were (re-)described by Martens (1986; in press $a, b, c)$. During these investigations a number of morphological peculiarities was observed and some were described, e.g. the socalled Müller-organ between the antennula and the antenna. The present contribution reports on another selected topic.

G. W. Müller $(1898,1900)$ was the first to describe the differences in the morphology of the antenna between males and females of two megalocypridinid species, namely Madagascarcypris voeltzkowi and Sclerocypris bicornis. But it was Gauthier (1951) who first questioned the homology of the different claws and setae for the same $S$. bicornis, admitting: "J'avoue ne pas comprendre à quoi correspondent ces griffes subterminales du mâle par rapport à celles de la femelle." (1951: 83).

Gauthier could not detect a correlation between the patterns in males and females because he overlooked a seta near aesthetasc $y_{2}$, which left him with 6 setae and claws in females compared to 5 in males. This is surprising, as Gauthier is generally known as a careful observer. The seta was nevertheless most likely present in his specimens, as observations on specimens from various collections of $S$. bicornis always clearly showed its presence (Martens, 1986). Relying solely on the morphology of the adult stage, Martens (loc. cit.) also failed to correlate the different structures, and following Gauthier's example, a different nomenclature was applied for both sexes.

Only after studying the morphology of the larval stages of some species could the problem unequivocally be solved. It appeared that even the cautious nomenclature of Martens (loc. cit.) failed to exclude all homeomorphies.

\section{MATERIAL AND METHODS}

The morphology of the antenna was studied in adult specimens of nearly all genuine Sclerocypris species, but these results have already been presented elsewhere (Martens, 1986; in press a \& b).

Material of (A-1) males of the following species was investigated: Sclerocypris venusta (Vávra, 1897) (Museum für Naturkunde der Humboldt-Universität zu Berlin, Zoologisches Museum, Berlin - no. 10014), S. coomansi Martens, 1986 (coll. by H. J. Dumont from Spitzkoppe, S.W. Africa-Namibia), and S. bicornis (G. W. Müller, 1900) (Zoologisches Institut und Zoologisches Museum, Hamburg - no. 1267). More data with regard to this material can be found in Martens (1986). Illustrations and descriptions in the present paper are mainly based on specimens of $S$. venusta. 


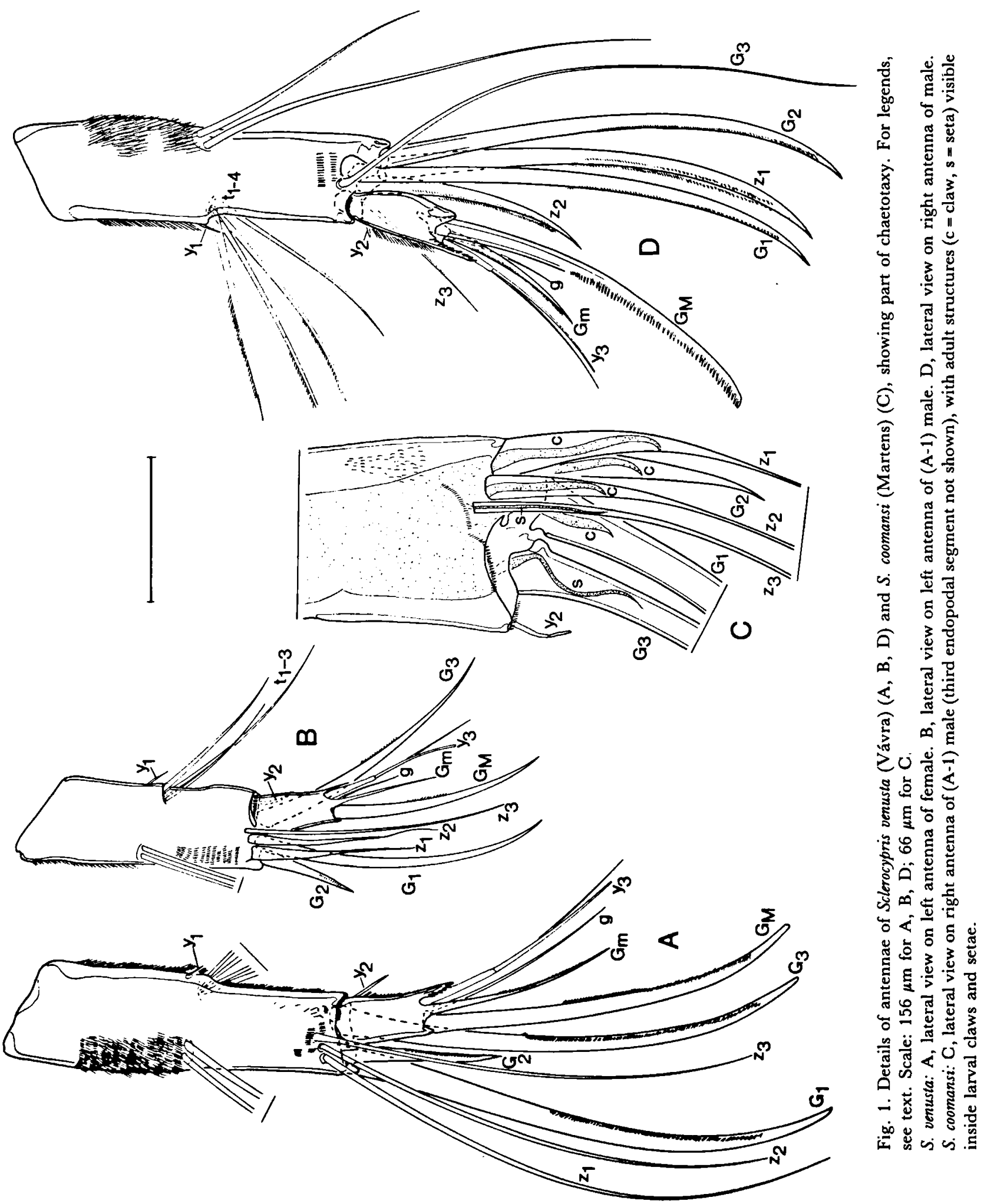


Diagrams in fig. 2 are schematic interpretations of imaginary apical views of the antennae and are based on numerous observations of these appendages before and after they were flattened by cover-slips.

The positions of the natatory setae (on the internal side of the antenna), of claw $G_{m}$ on the terminal segment (on the external side), of the terminal segment itself (slightly acentric, proximal to the body) and of the aesthetasc $y_{2}$ (proximal to the body) were used for the orientation of the limb. During inactivity and in the preserved state, the penultimate and the terminal segments are pointing downwards, assuming an angle of c. 90 degrees with the first endopodal segment. This causes difficulties in describing which sides of the segments are ventral, dorsal, etc. Therefore, the following rule is applied: the side of the first endopodal segment on which the aesthetasc $\mathrm{Y}$ is inserted, is called the ventral side. Through analogy, the same margin in the subsequent segments is also called the ventral margin (e.g. where $y_{1}$ is inserted on the second endopodal segment).

\section{RESULTS}

\section{Description of the antenna in adult females (fig. 1A)}

Protopodite 2-segmented and endopodite 3segmented. For the chaetotaxy of the protopodite, see Martens (1986). First podomere of endopodite large, with ventral aesthetasc (Y) short, stout and 3-segmented, 1 apical hair with swollen basis and $1+5$ natatory setae. Second segment of endopodite with 2 unequal, mediodorsal setae (inserted somewhat towards the external side), 4 unequal, ventrally situated t-setae and 1 short aesthetasc $\left(y_{1}\right)$, inserted proximally to the t-setae. This segment also with 3 subapical $z$-setae of similar length (inserted on the external side) and apically with 1 aesthetasc $\left(\mathrm{y}_{2}\right)$ and 2 long $\left(\mathrm{G}_{1}, \mathrm{G}_{3}\right)$ and 1 short $\left(\mathrm{G}_{2}\right)$ claws. Terminal segment with ventral apex exhibiting a toothed processus and apically bearing 1 large $\left(G_{M}\right)$ and 1 small $\left(G_{m}\right)$ claws, 1 seta $(\mathrm{g})$ and 1 bifurcated aesthetasc (y). Claws $G_{1}-G_{3}$ and $G_{M}$ set with a double row of small teeth.

The nomenclature of this limb in the female follows the one proposed by Broodbakker \& Danielopol (1982), because it has already been applied to a large number of other ostracod groups. To facilitate comparisons between the Megalocypridinae and those groups, the system proposed by Martens (1986; in press a) is here abandoned.

The subapical claws and setae on the penultimate segment of the female antenna can be named as follows (see diagrams, fig. 2): starting from the subventrally situated $y_{2}$, the first seta encountered when approached from the external side is $z_{3}$, the following $z_{2}$ and $z_{1}$, respectively. Both $z$ - and $t$-setae are numbered according to the sequence in which they occur during ontogeny (Danielopol, 1978; 1982). Of the 3 claws, the central one is called $G_{1} . G_{2}$ is the claw between $G_{1}$ and $z_{1}, G_{3}$ is inserted between $G_{1}$ and $y_{2}$. To recognize these structures on the lateral views of the antenna (fig. 1), the position of $y_{2}$ and of $G_{m}$ should be used as a reference.

\section{Description of the antenna in larval $(A-1)$ males (fig. 1B)}

Basically, the antenna in this larval stage of the male has the same chaetotaxy as in adult females. The following differences occur: there are 3 instead of $4 \mathrm{t}$-setae and the $3 \mathrm{z}$-setae are of a different morphology. Only $z_{3}$ has the shape of a normal, medium-sized seta; $z_{1}$ and $z_{2}$ both have a broad, stout base and narrow gradually to a flagellated apex and are thus clearly taking the appearance of claws, the former even more so than the latter. There is therefore no problem with regard to the nomenclature of apical claws and setae.

A male $S$. coomansi was preserved in a premoult condition, and future (adult) structures were already visible inside the transparent larval ornamentation. This proved immensely informative (fig. 1C). The most striking observations are that claws will emerge from $G_{1}, G_{2}$, $z_{1}$, and $z_{2}$, whereas setae are visible in the larval $z_{3}$ and in the large $G_{3}$. The latter was quite obvious and constitutes an important argument for the homologies proposed below.

Description of the antenna in adult males (fig. 1D)

Correct nomenclature for the claws and setae on the penultimate segment will be discussed 
below. Again, only differences with the female pattern will be cited here.

Only 1 short seta occurs on the external side of the second endopodal segment. There are furthermore 3 large and 1 short claws and a supplementary long seta on the internal side of that segment. Claw $\mathrm{G}_{M}$ on the terminal segment bears 1 row of stout teeth.

\section{DISCUSSION}

\section{Introduction}

Sexual dimorphism in the antenna is generally known in representatives of the Cyprididae s.s. (Danielopol, 1978), in a more limited way (change in size of z-setae) in Ilyocyprididae and Cyclocyprididae, absent in the Notodromatidae and even more pronounced in Candonidae, where (at least a number of) t-setae are modified to special "male bristles". In Cyprididae s.s. the dimorphism has been well documented only for some representatives of the Cyprinotinae (Broodbakker, 1982) and Megalocypridinae (Martens, 1986; in press a \& b). The pattern of the sexual dimorphism in these two groups is nearly identical.

Comparative research on this structure in various other subfamilies of the Cyprididae (more than 20) could reveal phylogenetic relations between the various taxa. For example, Martens (1985) and Martens \& Meisch (1985) briefly illustrated sexual dimorphism in some cypridopsine genera. In these groups, a different pattern can be detected from the one present in Cyprinotinae and Megalocypridinae. Based on such differences a number of cypridopsine genera might be united in a separate family, the Cypridopsidae, which was abandoned by DeDeckker (1979).

Danielopol (in various papers) illustrated sexual dimorphism in the antenna of many representatives of Candonidae and Darwinulidae and found again different patterns. All these data are, however, still far too fragmentary and compiling them is beyond the scope of this paper.

\section{Homology and nomenclature of the male antenna}

The fact that the chaetotaxy in (A-1) male larvae strongly resembles the female adult pattern (and far more than the male condition) is a strong argument to consider the female arrangement of claws and setae the plesiomorphic condition, whereas the situation in the male is clearly apomorphic. This is why the present nomenclature is based on the female morphology.

The arrangement (not morphology) of the claws, seta and aesthetasc on the terminal segment is identical in both males and females, and there can be no discussion with regard to the nomenclature of that aspect of the antennal chaetotaxy in males.

This is not so for the subapical claws and setae of the penultimate segment, however. Here, females have 3 claws and 3 grouped setae, whereas males have 4 claws and 2 setae, arranged according to a different pattern (cf. fig. 2). The careful nomenclature proposed by Martens (1986) still implied that a number of zsetae had either moved over considerable distances during the final moults or were newly grown.

The displacement and creation of structures constitutes one possible set of hypotheses to correlate the observed patterns. Martens (loc. cit.) never selected either of the two possibilities, but Broodbakker (1982), while (re-)describing different Heterocypris species from the West Indies, clearly opted for the displacement hypothesis. By naming the short seta near aesthetasc $y_{2}$ " $z_{2}$ ", for example, he postulated a 180 degree shift from the (original) position in the female. The mechanism of such a shift would be complicated, since claws and setae are mostly formed inside the larval structures (see above). Furthermore, no direct evidence of the existence of such mechanisms has been offered.

A second possible scheme accepts the plasticity of structures and morphology and a certain rigidity with regard to the relative location of the structure; claws can change (during moults) into setae and vice versa, but their relative arrangement remains approximately 


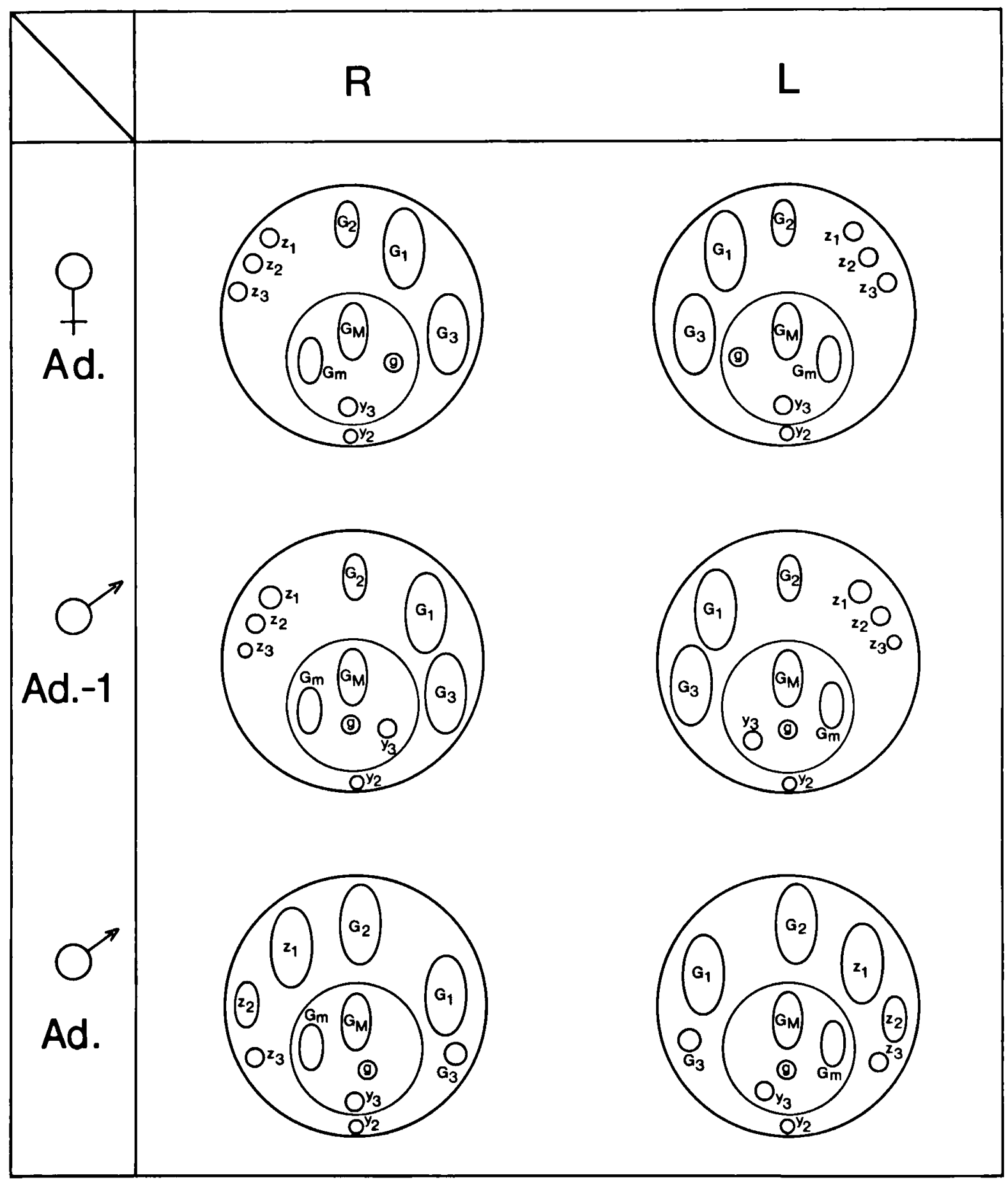

Fig. 2. Diagrams of imaginary apical views, showing position of subapical claws, setae and aesthetascs on endopodal segments 2 (large circles) and 3 (small circles) of the antenna of Sclerocypris venusta. The present diagrams are valid for all Sclerocypris species. Oval structures are claws, circles are setae. For interpretation of nomenclature, see text. 
the same. The present results offer strong support to this hypothesis. It appears, for example, that only 1 moult is required to change a large claw $\left(\mathrm{G}_{3}\right)$ into a seta, and only 2 moults are required to change 2 slender setae $\left(z_{2}, z_{3}\right)$ into stronger claws. This plasticity is important and must be taken into account when interpreting structures with a similar morphology. Generally, in order to distinguish between homologies and homeomorphies, the morphology of the (final) larval stages can offer important evidence and should always be assessed.

The male chaetotaxy can therefore be homologized as follows: $z_{3}$ has become a short and slender seta; $z_{2}$ has changed to a short claw and $z_{1}$ to a long one and both have altered their absolute positions slightly; $\mathrm{G}_{2}$, a short claw in the female, is a strong stout claw in the male; $G_{1}$ remains a long claw; and $G_{3}$, a strong claw in the female, is reduced to a long seta. To limit confusion in the literature, the nomenclature here proposed (figs. 1D, 2) is compared to the one used by Martens (1986) and Broodbakker (1982) in table I.

\section{TABLE I}

Comparison between 3 nomenclatorial systems, used to describe chaetotaxy of the antenna in males and females of Megalocypridinae and Cyprinotinae ( $=$ seta, $c=$ claw).

\begin{tabular}{|c|c|c|c|c|c|c|}
\hline \multicolumn{3}{|c|}{$\begin{array}{l}\text { Nomenclature } \\
\text { here proposed } \\
\text { (Megalocypridinae) }\end{array}$} & \multicolumn{2}{|c|}{$\begin{array}{l}\text { Martens (1986) } \\
\text { (Megalocypridinae) }\end{array}$} & \multicolumn{2}{|c|}{$\begin{array}{l}\text { Broodbakker } \\
\text { (1982) } \\
\text { (Cyprinotinae) }\end{array}$} \\
\hline symbol & 우 & $\sigma^{\prime}$ & q & $\sigma^{\circ}$ & q & $\sigma$ \\
\hline$z(1)$ & $\mathbf{s}$ & c & $z(3)$ & $G(3)$ & $z(1)$ & $G(1)$ \\
\hline$z(2)$ & $\mathbf{s}$ & c & $\mathrm{z}(2)$ & $z(c)$ & $z(2)$ & $z(1)$ \\
\hline$z(3)$ & $\mathbf{s}$ & $\mathbf{s}$ & $z(1)$ & $z(b)$ & $z(3)$ & $z(2)$ \\
\hline$G(1)$ & c & c & $G(2)$ & $G(1)$ & $G(1)$ & $G(3)$ \\
\hline$G(2)$ & c & c & $G(3)$ & $\mathrm{G}(2)$ & $\mathrm{G}(2)$ & $G(2)$ \\
\hline$G(3)$ & c & $\mathbf{s}$ & $G(1)$ & $z(a)$ & $G(3)$ & $z(3)$ \\
\hline
\end{tabular}

As the observed patterns in Megalocypridinae and Cyprinotinae are so similar, we can correct Broodbakker's interpretation relying on the present results. The sexual dimorphism in the Candonidae, however, is not so uniformly divided over the different subfamilies and genera. Some interpretations in the literature, which seem to be in disagreement with the present hypothesis can therefore not readily be assessed. For example, Danielopol (1982) accepted a 180 degree shift of $z_{2}$ and $z_{3}$ in adult males of Pseudocandona serbani (see also Broodbakker \& Danielopol, 1982). Danielopol (loc. cit.) studied z-setae in two juvenile stages of males and found that both shape and position of these setae in (A-1) juveniles are of the adult female type. The situation in these larvae can thus only be homologized with the one in adult males by studying the intermediate condition, namely the (A-1) larvae in premoult condition, in which both larval and adult structures are visible. The animal, however, lives in this condition for a limited amount of time only and such specimens can therefore be quite rare. It is here postulated that $z_{2}$ and $z_{3}$ in fig. $8 C$ of Danielopol (1982) are either reduced claws (the original $\mathrm{G}_{1}$ and $\mathrm{G}_{3}$ ) or constitute newly grown structures. The latter, however, is an entirely hypothetical possibility, as it has not been reported for ostracods to date.

\section{Function}

The main function of the antenna, in both males and females, is no doubt locomotion, either crawling or swimming. The medial position of the natatory setae does not seem to be the energetically most efficient solution for a swimming locomotion. Species of Sclerocypris, however, mostly crawl on the substrate (Sars, 1924; Cohen, 1986) and it is possible that the position of the antenna is temporarily altered if and when the organism swims for short distances. A second solution to the paradox may be related, at least in the female, to the presence of the long $z$-setae. It should be noted that the articulation between endopodal segments 2 and 3 exhibits a slight, but significant inward twist in most specimens, causing the $3 \mathrm{z}$-setae to assume a more ventrolateral instead of a lateral position. It is possible that the $z$-setae will compensate for the rotationforce vector, caused by the internally situated 
natatory setae during a power stroke, more efficiently than if in an entirely lateral position. There are indeed only 3 z-setae against $5+1$ natatory setae. It seems logical for this numerical discrepancy to be compensated by a positional alteration. This, however, should be investigated in extenso on living specimens.

There are different opinions, however, with regard to the use of the male antenna during copulation. The hypothesis that the antenna is used to grab and hold the female during copulation is extensively documented (Kaufmann, 1896; Jensen, 1904; Alm, 1916; McGregor \& Kesling, 1969). McGregor \& Kesling (loc. cit.) analysed the literature dealing with copulatory behaviour in ostracods and carried out new observations on various species. They reached the following conclusions: (1) most Cyprididae (except Notodromatinae - sic) observed assume a posterodorsal copulation position; (2) male prehensile palps only keep hold of the female during the actual copulation, whereas the initial contact is always made with the antennae.

Danielopol $(1978,1980)$, however, observed details of the copulatory behaviour of different species of Candoninae and of Limnocythere sanctipatrici and could not sustain these conclusions:

"My observations on living material [indicate] an important role of the setae and claws of the male [antenna] during a very short period of time before the insemination, like a sexual stimulans which determines the female to stop moving. There is no firm fixation of the male on the female. The difference in setae of the male probably [constitutes] a stimulans [...], specific for a group of species."

(Danielopol, pers. comm., 26.6.1987)

Similarly, Danielopol could see that the male bristles in Candoninae do not have a mechanical, but rather a chemoreceptive function. A similar function for the four aesthetascs on the antenna had already been established (Danielopol, 1973; 1978). McGregor \& Kesling (1969), on the other hand, suggested that these male bristles (modified t-setae) would serve to obtain a stronger grip on the female carapace during copulation.
We are thus left with two, quite opposite hypotheses on the function of the male antenna during copulation and are unable to apply either one of them to the Megalocypridinae, as we have not been able to observe copulatory behaviour in this group. The subject is nevertheless highly interesting, both for the functional morphology of the dimorphic chaetotaxy and for the phylogeny, and merits further elaboration.

\section{SUMMARY AND CONCLUSIONS}

Investigations of (A-1) males in premoult condition enabled us to correlate and homologize adult male and female antennal chaetotaxy. It appeared that the relative positions of the different claws and setae are rigid, but that shape and size can change substantially in the course of 1 or 2 moults. Because the male pattern is to all probability the apomorphic condition, a link between the differences in chaetotaxy and a special function during copulation appears obvious. Whether this function is to grab and hold the female before and/or during copulation or involves a more complicated, stimulating behaviour cannot be decided to date, as "in situ" observations of copulatory behaviour of megalocypridinids are lacking.

\section{ACKNOWLEDGEMENTS}

This paper greatly benefitted from discussions with Dr. D. Danielopol, who is also acknowledged for allowing me to use some of his unpublished observations of ostracod behaviour. Drs. K. Roche read the manuscript and made improvements. Mr. M. Bruyneel offered invaluable assistance with the illustrations. Material from the different museums was obtained through the efforts of Dr. E. Gruner (Berlin) and Prof. Dr. G. Hartmann and Mr. H. Petersen (Hamburg). The author is senior research assistant with the National Fund for Scientific Research (Belgium).

\section{REFERENCES}

ALM, G., 1916. Monographie der Schwedischen Süsswasser-Ostracoden, nebst systematischen Besprechungen der Tribus Podocopa. Zool. Bidr. Upps., 4: 1-248. 
Broodbakker, N. W., 1982. Amsterdam Expeditions to the West Indian Islands, Report 20. The genus Heterocypris (Crustacea, Ostracoda) in the West Indies. Part I. Taxonomic characters. Bijdr. Dierk., 52: 207-227.

Broodbakker, N. W. \& D. L. Danielopol, 1982. The chaetotaxy of Cypridacea (Crustacea, Ostracoda) limbs: proposals for a descriptive model. Bijdr. Dierk., 52: 103-120.

Conen, A. S., 1986. Distribution and faunal association of benthic invertebrates at Lake Turkana, Kenya. Hydrobiologia, 141: 179-197.

Danielopol, D. L., 1973. Sur la morphologie des aesthetascs chez quelques Ostracodes hypogés de la sous-famille des Candoninae (Cyprididae, Podocopida). Annls. Spéléol., 28: 233-245.

- , 1978. Über Herkunft und Morphologie der Süsswasser-hypogäischen Candoninae (Crustacea, Ostracoda): 1-162 (Springer Verlag, Wien/New York).

- - 1980. Sur la biologie de quelques Ostracodes Candoninae épigés et hypogés d'Europe. Bull. Mus. natn. Hist. nat. Paris, (4) (A, Zool.) 2 (2): 471-506.

- , 1982. Nouvelles données sur les Candoninae (Ostracoda) hypogés de Roumanie et Yougoslavie. Bull. Mus. natn. Hist. nat. Paris, (4) (A, Zool) 4 (3-4): 369-396.

DeDeckker, P., 1979. Evaluation of features distinctive in the taxonomy of the Cypridacea, above the generic level. In: Taxonomy, biostratigraphy and distribution of ostracodes: 9-17 (Serb. geol. Soc., Beograd).

Gauthier, H., 1951. Contribution à l'étude de la faune des eaux douces au Sénégal (Entomostracés): 1-161 (Minerva, Alger).

Jensen, S., 1904. Biologiske og systematiske undersøgelser over Ferskvands-Ostracoder. Vidensk. Meddr. dansk naturh. Foren., 56: 1-78, pls. I-III.

Kaufmann, A., 1896. Die Schweizerischen Cytheriden und ihre nächsten Verwandten. Revue suisse Zool., 4 (2): 313-384, pls. XII-XV.

McGregor, D. L. \& R. V. Kesling, 1969. Copulatory adaptations in ostracods. Part II. Adaptations in living ostracods. Contr. Mus. Paleont. Univ. Mich., 22 (17): 221-239.

Martens, K., 1985. Tanganyikacypridopsis n. gen. (Crustacea, Ostracoda) from Lake Tanganyika. Zoologica Scr., 14: 221-230.

--, 1986. Taxonomic revision of the subfamily Megalocypridinae Rome, 1965 (Crustacea, Ostracoda). Verh. K. Akad. Wetensch. Lett. Schone Kunsten Belg., (K1. Wetensch.) 48 (174): 1-81, figs. $1-64$.

- - in press a. On Sclerocypris pardii n. sp. (Crustacea, Ostracoda) from Somalia. Monitore zool. ital., (N.S.) Suppl. 22 (1).

- , in press b. Seven new species and two new subspecies of Sclerocypris Sars, 1924 from Africa, with new records of some other Megalocypridinids. Hydrobiologia (1987).

- - in press c. Additions to the description of Sclerocypris devexa (Daday, 1910) (Crustacea, Ostracoda), with a note on the position of this species. Biol. Jaarb. Dodonaea, 55 (1987).

Martens, K. \& C. Meisch, 1985. Description of the male of Potamocypris villosa (Jurine, 1820) (Crustacea, Ostracoda). Hydrobiologia, 127: 9-15.

Müller, G. W., 1898. Die Ostracoden. In: Wissenschaftliche Ergebnisse der Reisen in Madagaskar und Ostafrika in den Jahren 1889-1895 von Dr. A. Voeltzkow. Abh. Senckenb. naturforsch. Ges., 21 (2): 255-296, Taf. XIII-XIX.

,-- 1900 . Afrikanische Ostracoden, gesammelt von $\mathrm{O}$. Neumann im Jahre 1893. Zool. Jb., (Syst.) 13: 259268, Taf. 23.

SARs, G. O., 1924. The freshwater Entomostraca of the Cape Province (Union of South Africa). Ostracoda. Ann. s. afr. Mus., 20 (2): 105-193, pls. 2-20. 